\title{
DYNAMIC PERFORMANCE OF AN UNDERGROUND TRACKLESS RUBBER TYRED VEHICLE DRIVEN BY FLAMEPROOF DIESEL ENGINE
}

\author{
Jiusheng Bao, Shuai Yang, Shirong Ge, Peixin Han, Yan Yin
}

Original scientific papers

The trackless rubber tyred vehicle (TRTV) is an important transporting equipment of underground coal mine auxiliary transportation system in the world. Presently, most TRTVs are driven by flameproof diesel engine. However, few researches were focused on their dynamic performance in the past. In this paper, the characterizing parameters and influencing factors of the dynamic performance of a flameproof diesel engine driven TRTV were summarized and discussed firstly. Then the basic dynamic equations of the TRTV were established. Finally, the dynamic performances of the WCQ-3B type TRTV were simulated by ADVISOR. And some important dynamic performance parameters such as maximum speed, acceleration time and maximum gradability were discussed by simulation. What is more, the fuel economy and emission performance of the vehicle were also analysed. It is shown that the dynamic performance of WCQ-3B type TRTV can satisfy the design and usage requirements of underground coal mine.

Keywords: ADVISOR; dynamic performance; flameproof diesel engine; fuel economy; trackless rubber tyred vehicle

Dinamička učinkovitost podzemnog vozila bez gusjenica s gumenim kotačima pogonjenog vatrootpornim dizel motorom

Izvorni znanstveni članak Vozilo bez gusjenica s gumenim kotačima (the trackless rubber tyred vehicle - TRTV) važan je dio opreme za prijevoz u podzemnim ugljenokopima na svijetu. Sada se većina TRTV-a pogoni vatrootpornim dizel motorima. Međutim, malo je istraživanja do sada koja su bila usmjerena na njihovu dinamičku učinkovitost. U ovom se radu najprije rezimiraju i razmatraju karakteristični parametri i faktori od utjecaja na dinamičku učinkovitost TRTV-a pogonjenih vatrootpornim dizel motorima. Zatim se postavljaju osnovne dinamičke jednadžbe TRTV-a. Na kraju se ADVISOR-om simuliraju dinamičke performanse TRTV-a tipa WCQ-3B. Razmatraju se simulacijom neki važni parametri dinamičke učinkovitosti kao što su maksimalna brzina, vrijeme ubrzanja i maksimalna sposobnosti vozila u savladavanju uspona (gradabilnost). Uz to se također analiziraju potrošnja goriva i ispuštanje plinova. Pokazano je da dinamičke performanse WCQ-3B tipa TRTV-a mogu zadovoljiti zahtjeve dizajna i uporabe u podzemnim ugljenokopima.

Ključne riječi: vozilo bez gusjenica s gumenim kotačima (TRTV); vatrootporni dizel motor; dinamička učinkovitost; potrošnja goriva; ADVISOR

\section{Introduction}

Nowadays, the underground trackless rubber tyred vehicle (TRTV) is considered as one of the main auxiliary transportation equipment of coal mines [1]. At present, the designs of a tyred vehicle depend largely on experiences. The general developing way is to trial produce first and then remodel again, which lacks systemic design theories. The research of vehicle performance involves many aspects, such as system modelling, structural optimization, optimization methods, control strategy research and so on $[2 \div 7]$. However, the current researches of TRTV are mainly focused on the vehicle structure optimizations, system designs and exhaust treatment. For examples, Li [8] proposed a catalytic technology which can convert four kinds of harmful exhaust into harmless gases in order to achieve the goal of purification for TRTV. Guo [9] used finite element method to establish a TRTV rear frame entity model, which strengthened and improved the rear frame structure design. Duan [10] analysed the dynamic stress of the frame with finite element method under different working conditions. As it is known, the dynamic performance is one of the most basic and important performances of vehicles, which is just as important as coal mine auxiliary transportation equipment. The level of TRTV transport efficiency depends largely on the dynamic performance, which has also direct impacts on the vehicle fuel consumption, exhaust emissions and efficiency. However, few public literatures and researches were focused on the design of dynamic performance for the TRTV. In view of the current research problems, by taking the WCQ-3B flameproof diesel engine driven TRTV as an example, this paper established basic dynamic equations and simulated the dynamic performance and fuel economy of the TRTV, respectively.

\section{Dynamic performance equations}

\subsection{Mechanical structure}

Presently, most TRTVs use mechanical transmission, which is composed of flameproof diesel engine, explosion proof clutch, gearbox, transmission shaft, driving axle [11], shown as Fig. 1.



Figure 1 Schematic diagram of the mechanical transmission structure of flameproof diesel engine driven TRTV

Since the flameproof diesel engine is the only power source of a TRTV system, its dynamic performance determines the overall performance of the vehicle to a great extent. The effective performance indicators of the diesel engine include mainly: mean effective pressure, effective power, effective thermal efficiency, effective torque and specific fuel consumption. Among these, the effective power, effective torque and specific fuel consumption are closely related with the dynamic performance. While the specific fuel consumption can be 
reflected by the fuel consumption and the fuel consumption rate can be reflected through the throttle in a quantitative time. Therefore, in this paper, the effective power, effective torque and throttle opening were selected to reflect the dynamic performance of flameproof diesel engine.

The relationship between torque and power of a diesel engine can be expressed as the following.

$$
P=\frac{T_{\mathrm{tq}} n}{9550}
$$

where, $P$ is the engine effective power, $\mathrm{kW} ; T_{\mathrm{tq}}$ is the engine effective torque, $\mathrm{N} \cdot \mathrm{m} ; n$ is the output shaft speed, $\mathrm{r} / \mathrm{min}$.

The diesel engine throttle opening is related to the engine torque. Because the relationship between them is complex, it is still not possible to express it exactly by a mathematical equation. However, the relationship can be indicated by a function equation as the following [12].

$$
T_{\mathrm{tq}}=f(n, \alpha)
$$

where, $\alpha$ is throttle opening.

\subsection{Force analysis}

In order to analyse the dynamic performance of a TRTV, it is necessary to determine the motion characteristics of the vehicle at its running direction. Therefore, a variety of external forces at the TRTV driving direction should be mastered, which include: driving force and running resistance [13].

\subsubsection{Driving force}

The driving force of a TRTV comes from the torque of flameproof diesel engine which is transmitted to driving wheels through a transmission system. Therefore, the torque $T_{\mathrm{t}}$ acting on the wheel comes from the torque $T_{\mathrm{tq}}$ generated by the engine and the relationship between them can be expressed as follows [14].

$$
T_{\mathrm{t}}=T_{\mathrm{tq}} i_{\mathrm{g}} i_{0} \eta_{\mathrm{T}}
$$

where, $T_{\mathrm{t}}$ is torque on wheel, $\mathrm{N} \cdot \mathrm{m} ; T_{\mathrm{tq}}$ is engine torque, $\mathrm{N} \cdot \mathrm{m} ; i_{\mathrm{g}}$ is transmission ratio of gearbox; $i_{0}$ is transmission ratio of main reducer; $\eta_{\mathrm{T}}$ is mechanical efficiency of transmission system.

Then the driving force can be calculated by the following equation:

$$
F_{\mathrm{t}}=\frac{T_{\mathrm{tq}} i_{\mathrm{g}} i_{0} \eta_{\mathrm{T}}}{r}
$$

where, $F_{\mathrm{t}}$ is driving force on wheel, $\mathrm{N} ; r$ is wheel radius, m.

\subsubsection{Running resistances}

The TRTV must overcome a rolling resistance from the ground and a resistance from the air. And when climbing up a hill it has to overcome a component force of the gravity along the ramp, namely climbing resistance. What is more, there will be an acceleration resistance when it is accelerated [15].

(1) Rolling resistance

When moving, the tires contact with the ground to produce an interaction force. The rolling resistance on the wheel from the ground acts on the deviation of vehicle traveling direction. It can be equivalently substituted by a horizontal force, which acts on the wheel centre and points in the opposite direction of movement.

$F_{\mathrm{f}}=M g f_{\mathrm{f}} \cos \theta$

where, $M$ is vehicle mass, $\mathrm{kg}$; $\mathrm{g}$ is gravity acceleration; $F_{\mathrm{f}}$ is rolling resistance, $\mathrm{N} ; f_{\mathrm{f}}$ is rolling resistance coefficient; $\theta$ is ground slope angle, ${ }^{\circ}$.

The rolling resistance coefficient $f_{\mathrm{f}}$ depends mainly on tire conditions (material, structure, pressure, surface geometry and temperature) and road states (roughness, material and wet or not). Generally, the rolling resistance coefficient of a TRTV moving on a concrete hardened road can be taken as 0.02 to 0.035 .

(2) Air resistance

The air resistance comes from air which has great relationships with the vehicle body shape. Usually, it can be expressed as proportional to the dynamic pressure of flow relative density [16].

$$
F_{\mathrm{w}}=\frac{C_{\mathrm{D}} A u_{\mathrm{r}}^{2}}{21,15}
$$

where, $F_{\mathrm{w}}$ is air resistance, $\mathrm{N} ; C_{\mathrm{D}}$ is air resistance coefficient; $A$ is frontal area, that is the projection area of a vehicle towards its running direction, $\mathrm{m}^{2} ; u_{\mathrm{r}}$ is relative velocity, $\mathrm{m} / \mathrm{s}$.

(3) Climbing resistance

When climbing a hill, the vehicle's weight will produce a component force parallel to the downhill direction. The climbing resistance can be expressed as follows:

$$
F_{\mathrm{i}}=M \mathrm{~g} \sin \alpha
$$

where, $F_{\mathrm{i}}$ is climbing resistance, $\mathrm{N}$.

The ground slope angle $a$ can be substituted by a ground slope value $i$ when it is very small.

$$
F_{\mathrm{i}}=M \mathrm{~g} i
$$

\section{(4) Acceleration resistance}

The acceleration resistance is an inertia force that a vehicle needs to overcome when it is accelerating. The vehicle produces not only moving mass inertia force, but also rotational inertia force. When calculating, the rotational inertia force can be translated and added into the moving mass inertial force [17].

$$
F_{\mathrm{j}}=\delta M \frac{\mathrm{d} u}{\mathrm{~d} t}
$$


where, $\delta$ is the vehicle rotating mass conversion factor.

According to these analyses above, the dynamic equilibrium equation which indicates the relationship between driving forces and the resistances of a TRTV can be expressed as the following:

$$
F_{\mathrm{t}}=F_{\mathrm{f}}+F_{\mathrm{w}}+F_{\mathrm{i}}+F_{\mathrm{j}}
$$

After determining these parameters, it can be used as a basic equation to analyse the driving capacities, dynamic performances and loading properties of a TRTV.

\subsection{Evaluation index of dynamic performance}

In general, the dynamic performance can be assessed by three indexes: maximum speed, acceleration time and maximum gradability $[18,19]$. What is more, the fuel economy can also be an index reflecting the dynamic performance from another side [20]. In view of the actual working conditions of a TRTV used in underground coal mine, its dynamic performance can be evaluated by several indexes as follows:

(1) Maximum speed

The maximum speed is the highest velocity that a fully loaded vehicle can reach at a good level road. According to the actual conditions in coal mines, the maximum speed of a TRTV is generally 20 to $40 \mathrm{~km} / \mathrm{h}$.

(2) Acceleration time

Both the starting acceleration time and overtaking acceleration time can be used to score a TRTV's acceleration performance. Generally, the acceleration time from 0 to $20 \mathrm{~km} / \mathrm{h}$ is selected to show the ability of starting acceleration ability. While the acceleration time from $20 \mathrm{~km} / \mathrm{h}$ to the maximum speed indicates the overtaking acceleration ability.

(3) Maximum gradability

The maximum gradability is the highest slope that a TRTV can climb with its first gear. According to the general management regulations of TRTVs [11], the roadway slope for a normal running should be less than $5^{\circ}$, the roadway slope of auxiliary transportation should be less than $7^{\circ}$. And the maximum gradient should be no higher than $10^{\circ}$ even in particularly difficult working conditions.

\subsection{Influence factors of dynamic performance}

The dynamic performance is closely related to vehicle structure parameters of the vehicle, the vehicle load and road conditions, and affecting factors of TRTV dynamic performance can be roughly divided into the following several aspects $[21,22]$ :

(1) Engine parameters

The engine power, torque and structure parameters have great influence on the dynamic performance of a TRTV. When the transmission ratio is fixed, the larger the maximum engine torque is, the stronger the acceleration performance and climbing capacity are. Since the basic structure and parameters of the engine affect the output of engine torque and power, it will affect the dynamic performance of a TRTV, too.

(2) Transmission parameters
The higher transmission efficiency is, the smaller the power loss will be, and the better power performance a TRTV will have. When a TRTV is driving at its lowest gear position, it must be ensured to have the maximum driving force to have the ability to overcome the maximum resistance. With more transmission gear selections, the engine will have more opportunities to improve the dynamic performance of a TRTV during the process of acceleration or resistance changing.

(3) Vehicle mass

Obviously, the dynamic performance is inversely proportional to the vehicle mass under same conditions. Once the vehicle mass is reduced, all driving resistance will be reduced. Therefore, the mass reduction of a TRTV can help to improve its dynamic performance.

(4) Tire structure parameters

The driving force, rolling resistance and adhesion are related to the tire structure parameters. Therefore, the choice of tires has certain influence on the dynamic performance. Among which, the tire radius, form and pattern all have impacts on the dynamic performance of a TRTV.

(5) Road conditions

The road conditions of underground coal mine are changeable, and the working environment is poor, which also affects the dynamic performance of a TRTV.

\subsection{Fuel economy}

The vehicle fuel economy is commonly measured by the fuel consumption when driving $100 \mathrm{~km}$ under a certain operation or by the driving mileage with a quantitative fuel [23]. In China, the unit L/100 km is used to score the fuel economy of a TRTV, namely the fuel consumption litters per driving $100 \mathrm{~km}$. With the same loading weight, the smaller number is, the better fuel economy the TRTV has.

\section{Dynamic performance simulations}

Since there are many factors that affect the vehicle dynamic performance, it is difficult to use any theoretical model or formula to calculate its dynamic performance directly. Generally, a more effective method is to calculate by simulation with specialized software. At present, there is no specific simulation software for TRTVs. Therefore, in this paper the Advanced Vehicle Simulator (ADVISOR) software which was developed by the America Renewable Energy Laboratory was used to simulate the dynamic performance of TRTVs. The ADVISOR software is open access which can give the analysis of dynamic performance, fuel economy and emission performance of various types of vehicles such as traditional vehicles, pure electric vehicles and hybrid vehicles in terms of certain road conditions [24].

\subsection{Vehicle parameters setting}

The WCQ-3B type TRTV driven by a flameproof diesel engine was selected as a sample to verify the design rationality of dynamic performance by using the ADVISOR software. Tab. 1 presents the main structure and technical parameters of the vehicle. 
Table 1 Structure and technical parameters of the WCQ-3B flameproof diesel driven TRTV

\begin{tabular}{|c|c|}
\hline Parameters & Values \\
\hline Whole vehicle kerb mass $(\mathrm{kg})$ & 7500 \\
\hline Rated load mass (kg) & 3000 \\
\hline Overall dimension (long $\times$ wide $\times$ high, $\mathrm{mm} \times \mathrm{mm} \times \mathrm{mm}$ ) & $6000 \times 1900 \times 2000$ \\
\hline Tire diameter $(\mathrm{m})$ & 1 \\
\hline Running speed $(\mathrm{km} / \mathrm{h})$ & $0 \div 33$ \\
\hline Gradability $\left(^{\circ}\right)$ & 14 \\
\hline Minimum turning radius $(\mathrm{mm})$ & 6000 \\
\hline Minimum ground clearance $(\mathrm{mm})$ & 280 \\
\hline Engine model & CKS4105FB \\
\hline Engine power rating $(\mathrm{kW})$ & 50 \\
\hline 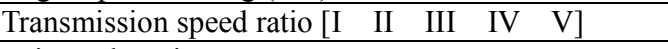 & $\begin{array}{lllll}5,534 & 3,111 & 1,73 & 1 & 0,818 \\
\end{array}$ \\
\hline Drive axle ratio & 18,943 \\
\hline
\end{tabular}

Although there are no specify models for TRTVs in the ADVISOR software, the simulation model can still be established to meet the requirements of a flameproof diesel engine driven TRTV by modifying the parts of basic vehicle models. As mentioned before, most TRTVs adopt a mechanical transmission mechanism similar to traditional automobiles. Therefore, the vehicle simulation system in the ADVISOR was built as shown in Fig. 2.

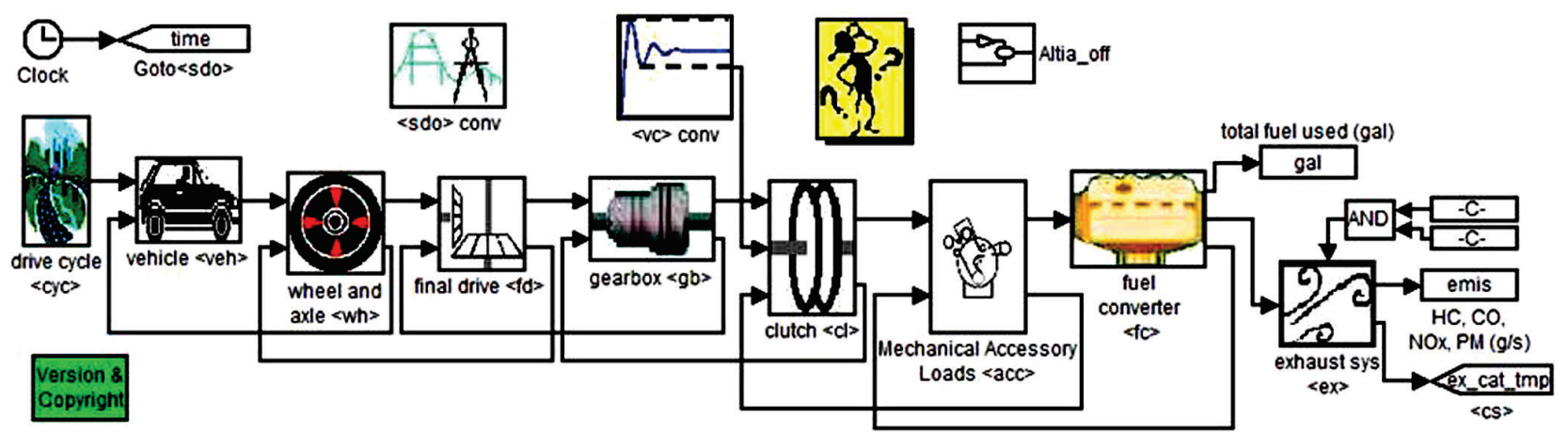

Figure 2 Simulation model of a flameproof diesel engine driven TRTV

Table 2 Setting of component parameters

\begin{tabular}{|c|c|}
\hline Component parameters & Values \\
\hline fc_max_pwr (engine peak power, kW) & 90 \\
\hline fc inertia (engine rotational inertia, $\mathrm{kg} \cdot \mathrm{m}^{2}$ ) & 0,4 \\
\hline fc_disp (engine displacement, L) & 4,94 \\
\hline fd_ratio (final drive ratio) & 18,943 \\
\hline gb_gears_num (transmission gear number) & 5 \\
\hline gb_ratio (transmission speed ratio) & {$\left[\begin{array}{lllll}5,534 & 3,111 & 1,73 & 1 & 0,818\end{array}\right]$} \\
\hline wh_radius (wheel rolling radius, $\mathrm{m}$ ) & 0,5 \\
\hline wh_1st_rrc (wheel rolling resistance coefficient) & 0,02 \\
\hline wh inertia (wheel rotational inertia, $\mathrm{kg} \cdot \mathrm{m}^{2}$ ) & 22,5 \\
\hline veh_CD (vehicle drag coefficient) & 0,58 \\
\hline veh_FA (vehicle frontal area, $\mathrm{m}^{2}$ ) & 3,8 \\
\hline veh_cargo_mass (vehicle cargo mass, $\mathrm{kg}$ ) & 3000 \\
\hline veh_cg height (vehicle centre of gravity height, m) & 1 \\
\hline veh_glider_mass (vehicle kerb mass, kg) & 7500 \\
\hline veh_front_wt_frac (vehicle front axle load ratio) & 0,35 \\
\hline veh_wheelbase (vehicle wheelbase) & 3,05 \\
\hline
\end{tabular}

ADVISOR uses a hybrid simulation method, which combines forward simulation and backward simulation. Firstly, the backward simulation method was adopted. According to the driving condition requirements provided by drive cycle module, the driving force required for vehicle is transmitted to the vehicle module, and then converted to the speed and torque required for wheel 's rotation in wheel and axle module. The speed and torque are transmitted to the fuel converter module and finally the power which needs to be provided by engine is calculated after the final drive module and gearbox module. Then the forward simulation method was adopted. The energy is transmitted step by step until the wheel and axle module, and the actual wheel speed is calculated. In addition, the energy loss in transmission should be considered. In the above process, the driving force can be calculated according to the vehicle speed, and the relationship between torque and driving force can be obtained by formulas. Finally, the engine output power can be got. The above can be calculated by the formula $(1) \div(10)$.

Various parameters of the TRTV can be input through the interface of vehicle to define its personality. 
According to the mechanical transmission system of TRTV, the components needs to select and define include: vehicle, fuel converter, exhaust after treat, transmission, wheel/axle, accessory, powertrain control. Because the ADVISOR software does not have any TRTV special simulation modules, the components of WCQ-3B type TRTV were actually selected as a similar Kenworth vehicle models (VEH_KENT) when modelling basic vehicle structures. And then all the parameters of these components were modified according to the structure and technical parameters of the WCQ-3B type TRTV and the results are shown in Tab. 2. Among which, because the ADVISOR software does not have a component which can simulate the wheel side reducer used in the WCQ-3B type TRTV, its transmission ratio was treated as an additional part of the main reducer.

\subsection{Simulation tasks setting}

\subsubsection{Selection of cycle condition}

Since the road conditions are complex and changeable, the vehicles will appear with frequent idle stops, accelerations, decelerations in a driving process. On the basis of tracking test and statistics of actual vehicles, several typical cycle conditions had been built to simulate the vehicle running situations. And the $100 \mathrm{~km}$ fuel consumption was used to evaluate their corresponding fuel economy. At present, the ADVISOR software supplies several common cycles: New York City Cycle (CYC_NYCC), EPA Urban Dynamometer Driving Schedule (CYC UDDS), City-Suburban Heavy Vehicle Route (CYC_CSHVR), etc. The selection of cycles should be combined with the actual use of vehicle design. It is important to choose a reasonable cycle in order to get more accurate simulation of the vehicle dynamic performance [25].

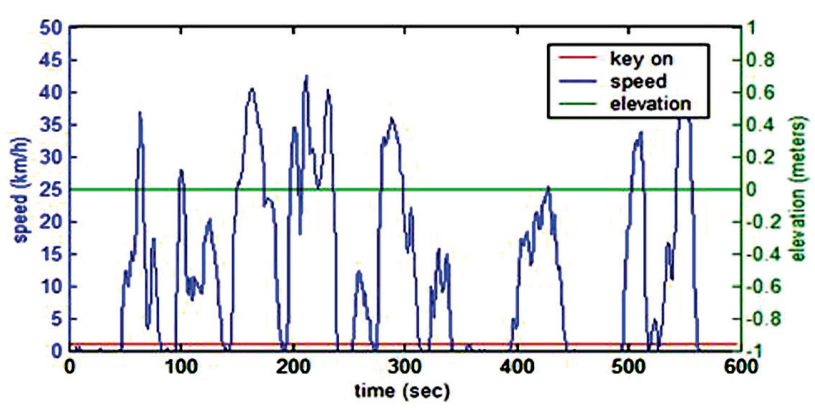

Figure 3 Speed-time curve of the CYC_NYCC standard cycle

Table 3 Basic dynamic performance of the CYC_NYCC standard cycle

\begin{tabular}{|l|c|}
\hline \multicolumn{1}{|c|}{ Dynamic performance parameters } & Values \\
\hline Time $(\mathrm{s})$ & 598 \\
\hline Distance $(\mathrm{km})$ & 1,9 \\
\hline Max speed $(\mathrm{km} / \mathrm{h})$ & 44,58 \\
\hline Average speed $(\mathrm{km} / \mathrm{h})$ & 11,41 \\
\hline Maximum acceleration $\left(\mathrm{m} / \mathrm{s}^{2}\right)$ & 2,68 \\
\hline Maximum deceleration $\left(\mathrm{m} / \mathrm{s}^{2}\right)$ & $-2,64$ \\
\hline Number of stops & 18 \\
\hline Idle time $(\mathrm{s})$ & 210 \\
\hline
\end{tabular}

The underground TRTV driven by a flameproof diesel engine is designed mainly for carrying workers, materials and small tools. It is a light vehicle having lower speed and fixed transport route. According to The general technical condition of the flameproof diesel vehicle with the rubber wheels for the mine [26], the maximum speed of TRTV should be limited to $40 \mathrm{~km} / \mathrm{h}$ when transporting goods and to $25 \mathrm{~km} / \mathrm{h}$ when transporting personnel, and the braking distance of TRTV should be no more than $8 \mathrm{~m}$ at $20 \mathrm{~km} / \mathrm{h}$ with rated load. At present, the standard underground condition has not been established in China. By contrast of the max speed, average speed, maximum acceleration and other parameters of various cycles provided by the ADVISOR software, it was found that the America CYC_NYCC standard cycle is very similar to the actual working conditions of the WCQ-3B type TRTV. Therefore, the CYC NYCC standard cycle was selected, whose speed-time curve is shown in Fig. 3 and basic dynamic performance data are shown in Tab. 3 .

\subsubsection{Setting of acceleration and climbing parameters}

The acceleration performance is closely related to the vehicle average speed. The ADVISOR software can observe both the starting acceleration time and overtaking acceleration time at the same time. The acceleration time of 0 to $25 \mathrm{~km} / \mathrm{h}$ and 25 to $40 \mathrm{~km} / \mathrm{h}$ was used in simulation to score the acceleration ability of starting and overtaking, respectively. And when setting the climbing performance parameters, the climbing speed of the TRTV at its first gear was set as $4.5 \mathrm{~km} / \mathrm{h}$ to simulate the maximum gradability.

\section{Results and discussion 4.1 Cycle speed}

Fig. 4a) shows a contrast curve of the demand speed (blue lines) and simulation speed (red lines) when the TRTV is running at the first cycle under the CYC_NYCC standard cycle conditions. It is found that as a whole the red lines and blue lines are consistent most time, which indicates that the power output of the WCQ-3B type TRTV can basically meet the standard cycle speed requirements. However, it is also seen that the red lines and blue lines do not completely overlap at many places, which means that there is still a certain gap between the actual and demand speed. The difference may be attributed to the following reasons. Firstly, there are no special modules for TRTVs in the ADVISOR software, so a similar vehicle Kenworth models (VEH_KENT) was selected when modeling. However, their component parameters have certain deviations themselves. Secondly, for lack of TRTVs related structure parameters and experimental data, some of the parameters cannot be accurately set in the software and have to use default values when modeling. For example, the average heat capacity of launch cabin and canopy (fc_h_cp), the engine surface area (fc_ext_sarea), the quality of main reducer's driving shaft (fd_mass). Therefore, the approximate treatments on vehicle structures and parameters make the differences between simulation results and ideal values.

By comparison, the coincidence degree of curves in the front half cycle (before $300 \mathrm{~s}$ ) is obviously worse than it is at the back half cycle (after $300 \mathrm{~s}$ ). And it can also be seen that at most time the simulation speed (red lines) is 
lower than the demand speed (blue lines) in the front half cycle. It is indicated that the TRTV lacks power in the front half cycle. The reason may be explained as follows. Because the engine was just started in the front half cycle, it has not entered a heated engine state. The moving parts were not sufficiently lubricated which as a result caused the poor output engine characteristics and vehicle dynamic performance.

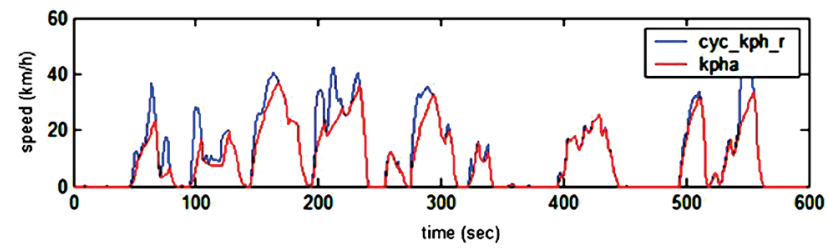

a) First cycle

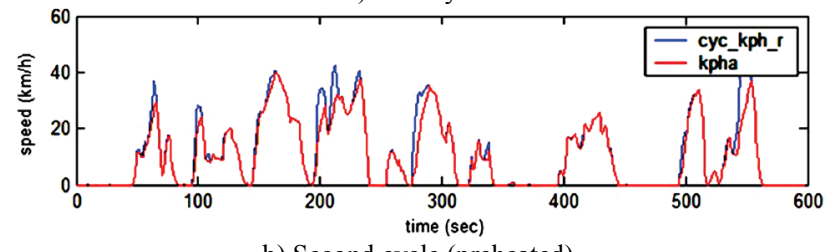

b) Second cycle (preheated)

Figure 4 Speed curves of demand and simulation under the CYC_NYCC standard conditions

In order to verify this conjecture, the speed curves of the TRTV under the second cycle when the engine has been fully preheated were simulated as shown in Fig. 4b). It is found that the conformity of speed curves in the front half was obviously improved which proved that the above conjecture may be correct. Therefore, in order to achieve an excellent power output performance, the diesel engine should be fully preheated before transporting materials.

Furthermore, it is observed from both Fig. 4a) and Fig. $4 \mathrm{~b}$ ) that the simulation speed is always lower than the demand speed at acceleration stages. That is to say, there exists obviously a lag phenomenon in the acceleration of diesel engine. This is due to the characteristics of diesel engine. The diesel has poor combustion ability, which is not easy to be ignited. What is more, the diesel engine works based on compression ignition, which needs to compress air to generate heat for igniting combustible mixture gases. All of these factors slow down the combustion speed of diesel in the cylinders, which as a result leads to a slow response of diesel engine and a poor acceleration performance of vehicle. However, because of working principles of diesel engine, these problems cannot be fundamentally solved. And at present only some partial improvements can be done such as optimizing the shape of combustion chamber, using a turbocharging technology, and so on.

\subsection{Dynamic performance}

The simulation results of the dynamic performance of WCQ-3B type TRTV are given in Tab. 4. By comparison of the design parameters in Tab. 1 , it is found that the dynamic performance can basically meet the design requirements. The maximum speed obtained by simulation is $40 \mathrm{~km} / \mathrm{h}$ which is higher than the design requirement of $33 \mathrm{~km} / \mathrm{h}$. And the simulation of maximum gradability is $14.04^{\circ}$ which can also satisfy the design requirement $14^{\circ}$.
Table 4 Simulation results of dynamic performance

\begin{tabular}{|l|c|c|}
\hline \multicolumn{1}{|c|}{ Dynamic performance index } & $\begin{array}{c}\text { Simulation } \\
\text { values }\end{array}$ & $\begin{array}{c}\text { Design } \\
\text { values }\end{array}$ \\
\hline Maximum speed $(\mathrm{km} / \mathrm{h})$ & 40 & 33 \\
\hline Maximum gradability $\left(^{\circ}\right)$ & 14,04 & 14 \\
\hline $0-25 \mathrm{~km} / \mathrm{h}$ acceleration time $(\mathrm{s})$ & 6,9 & \\
\hline $25-40 \mathrm{~km} / \mathrm{h}$ acceleration time $(\mathrm{s})$ & 8,7 & \\
\hline $0-40 \mathrm{~km} / \mathrm{h}$ acceleration time $(\mathrm{s})$ & 15,7 & \\
\hline
\end{tabular}

Because there are no specific design parameters on the acceleration time in Tab. 1, also because there are no specific regulations on the acceleration time within the national technical standard MTT989-2006 [26], it is difficult to evaluate directly whether the acceleration time reflected in Tab. 4 can meet the design requirements. Therefore, in order to evaluate accurately the dynamic performance of TRTVs, it is necessary to establish or improve relevant technical standards, to clear dynamic performance indexes, to build evaluation methods in the future.

\subsection{Fuel economy and emission performance}

The fuel economy can also be used as a side index to evaluate whether the vehicle's dynamic parameters are reasonably designed. As shown in Tab. 5, the simulation of $100 \mathrm{~km}$ fuel consumption is 59,11 .

Table 5 Simulation results of fuel economy performance

\begin{tabular}{|c|c|c|}
\hline $\begin{array}{c}\text { Fuel economy performance } \\
\text { index }\end{array}$ & $\begin{array}{c}\text { Simulation } \\
\text { value }\end{array}$ & Actual value \\
\hline Fuel consumption $(1 / 100 \mathrm{~km})$ & 59,1 & 110 \\
\hline
\end{tabular}

Although there is no such a design date in Tab. 1, according to relevant statistics the actual average fuel consumption of this type of TRTV is about 1101 per 100 $\mathrm{km}$. The reason why the simulation result is far lower than the actual fuel consumption may be attributed to the selection of a standard cycle. The CYC NYCC standard cycle was built according to ground vehicles and road conditions. However, the working environment such as road, ventilation conditions may be quite different with a mine TRTV working underground. What is more, for safety working in the underground, the flameproof diesel engine has to be explosion proofed both on its air inlet and outlet system. The flameproof structures result in insufficient combustion of diesel fuel and low working efficiency of vehicle.

There are a lot of harmful components such as hydrocarbon $(\mathrm{HC})$, carbon monoxide $(\mathrm{CO})$, nitrogen oxide $\left(\mathrm{NO}_{\mathrm{X}}\right)$ and dust particles (PM) in the exhaust gas emission of a diesel engine. Particularly, when it is working in a coal mine tunnel, for the limitation of space and ventilation conditions, the exhaust gas emission seriously endangers the health of coal mine workers. Therefore, it is very important to control and manage the exhaust emission of TRTVs working underground [27]. The national standard MTT 989-2006 [26] has some specific regulations: the volume concentration of carbon monoxide may not be higher than $0.1 \%$ and the nitrogen oxides should be lower than $0.08 \%$ in an undiluted exhaust.

Both the volume concentration and mass-volume concentration can be used to represent the pollutant 
content. And these two different units can be achieved through a conversion formula as follows:

$$
X=\frac{M C \times 10^{4}}{22.4}
$$

where, $C$ is volume concentration, $\% ; X$ is mass-volume concentration, $\mathrm{mg} / \mathrm{m}^{3} ; M$ is molecular weight of gas.

Since the WCQ-3B type TRTV is mainly used in a coal mine roadway section of not less than $3 \mathrm{~m} \times 3 \mathrm{~m}$, the simulation emission indexes can be conversed as shown in Tab. 6. It is shown that the vehicle emission results are in conformity with the relevant requirements of coal mine underground. However, it is necessary to point out that the simulation results of emission performance shown in Tab. 6 are calculated by the ADVISOR software according to the CYC NYCC standard cycle conditions. While for a flameproof diesel engine driven TRTV working in underground coal mine, its actual emissions must have inevitable difference with the simulations.

Table 6 Simulation results of emission performance

\begin{tabular}{|l|c|c|c|c|c|}
\hline \multicolumn{1}{|c|}{ Emission performance indexes } & $\mathrm{HC}$ & $\mathrm{CO}$ & $\mathrm{NO}_{\mathrm{X}}$ & PM & Total \\
\hline Simulation values (g/km) & 0,807 & 2,983 & 10,473 & 0,424 & 14,687 \\
\hline Conversion values (\%) & 0,000015 & 0,000026 & 0,000087 & & \\
\hline Specific values in MTT989-2006 (\%) & & $<0.1$ & $<0.08$ & & \\
\hline
\end{tabular}

\section{Conclusions}

As an important equipment of underground transportation system, the TRTV driven by flameproof diesel engine has been widely used in coal mines. However, the researches on its dynamic performance and fuel economy are not sufficient at the present. Based on the basic analysis on scoring indexes and their influence factors of dynamic performance, this paper established basic dynamic equations, simulated the dynamic performance of WCQ-3B type TRTV by the ADVISOR software. And the main conclusions are summarized as follows:

1) The dynamic performance of a TRTV driven by flameproof diesel engine should be evaluated according to the underground coal mine working conditions. The main evaluation indexes of dynamic performance should generally include: maximum speed, acceleration time and maximum gradability. Also the fuel economy and emission performance should be comprehensively considered. However, the technology and system for evaluating the dynamic performance of TRTVs driven by flameproof diesel engine have not been established in the existing national standards of coal industry.

2) The factors that determine and affect the dynamic performance of a TRTV include: engine, transmission system, shape structure, vehicle mass, tire structure and working conditions. Among them, the lacking of ventilation in the underground and explosion-proof requirements are major factors which limit the dynamic performance of TRTVs.

3) The ADVISOR software can be used as an approximate method for dynamic performance simulation of TRTVs. Based on the simulation results of the WCQ-3B type TRTV, it is shown that its dynamic performance can meet the requirements of the design and usage in underground coal mine.

4) For lack of specific cycle data of coal mine underground, the ADVISOR software is difficult to evaluate accurately the fuel economy and emission performance of a TRTV driven by flameproof diesel engine. Therefore, it is necessary in the future to do secondary developments of the ADVISOR software or new developments of specific software for TRTVs. What is more, a standard cycle conditions database for TRTVs should also be gradually established according to the underground coal mine environments and working conditions.

\section{Acknowledgments}

This study was financially supported by the Fundamental Research Funds for the Central Universities in China (Grant No. 2014ZDPY10), and the Priority Academic Program Development of Jiangsu Higher Education Institutions.

\section{References}

[1] China Coal Construction Development Corporation. Selection and calculation of modern mine auxiliary transportation equipment. Beijing: China Coal Industry Publishing House, 1994.

[2] Mitić, S.; Rakićević, B.; Stamenković, D.; Popović, V. Advanced theoretical-experimental method for optimization of dynamic behaviour of firefighting vehicle modular superstructures. // Journal of Applied Engineering Science (Istraživanja i projektovanja za privredu). 9(2011), pp. 267-275.

[3] Evgeni Nikolaevich, B.; Ildar Nyryaiazovich, B.; Sergeivich Stepan, Z. Enhancing the stability of timber harvesting machine of manipulator type by using the active suspension system. // Journal of Applied Engineering Science (Istraživanja i projektovanja za privredu). 2, 12(2015), pp. 111-116.

[4] Huusom, J. K.; Poulsen, N. K.; Jørgensen, S. B. Iterative feedback tuning of uncertain state space systems. // Brazilian Journal of Chemical Engineering. 27, 3(2010), pp. 461-472. https://doi.org/10.1590/S0104-66322010000300010

[5] Precup, R. E.; Dragos, C. A.; Preitl, S.; Radac, M. B.; Novel tensor product models for automatic transmission system control. // IEEE Systems Journal. 6, 3(2012), pp. 488-498. https://doi.org/10.1109/JSYST.2012.2190692

[6] Čelović, S.; Tipsarevic, M.; Maneski, T.; Vuherer, T.; Kozak, D. Numerical-experimental analysis of the foldable containers strength. // Technical Gazette. 22, 6(2015), pp. $1527-1532$

[7] Türkşen, Ö.; Tez, M. An application of Nelder-Mead heuristic-based hybrid algorithms: Estimation of compartment model parameters. // International Journal of Artificial Intelligence. 14, 1(2016), pp. 112-129.

[8] Junwei Li; Xinqian Shu; Cheng Li; Xingmin Fu; Shida Li; Ming Li. Review of pollutants control technology caused by trackless rubber-tyed vehicle emission in underground coal mine. // Coal Science and Technology. 41, 9(2013), pp. 
386-389. https://doi.org/10.13199/j.cnki.cst.2013.s2.141

[9] Peiyan Guo; Haixing Zhao; Long Xie; Jian Li. Improvement research on the rear frame of trackless rubber-tyred vehicle based on finite element method. // Mining \& Processing Equipment. 38, 1(2010), pp. 41-44.

[10] Nengquan Duan; Wenhua Du; Yanmei Chen; Lei Dong; Junyuan Wang. Research on dynamic characteristics of explosion-proof rubber-tyred vehicle on multi-road conditions. // Coal Mine Machinery. 36, 6(2015), pp. 151-153.

[11] Hanjun Jiang. Transporting equipments of coal mine auxiliary. Xuzhou: China University of Mining and Technology press, 2008

[12] Zhongyi Xuan. Diesel engine dynamics model based on system identification method. // Bulletin of Science and Technology. 28, 1(2012), pp. 117-121. https://doi.org/10.3969/j.issn.1001-7119.2012.01.023

[13] Jianzhang Feng. Engine principle and theory of vehicle. Beijing: China Machine Press, 1999.

[14] Wenzhe Li; Qichuan Xu. Automobile and tractor - chassis structure and vehicle theory. Beijing: China Agriculture Press, 2006.

[15] Zhisheng Yu. Theory of vehicle. Beijing: China Machine Press, 2000.

[16] Nanhai, Ye; Huixin, Guo. Automotive air resistance analysis. // Journal of Changde Teachers University (Natural Science Edition). 12, 4(2000), pp. 26-28.

[17] Feng Xie; Jun Sheng; Bo Liu; Juguang Lin. The development of variable loading device of online test rig for automobile gearbox. // Modular Machine Tool \& Automatic Manufacturing Technique. 7(2007), pp. 46-49.

[18] Jilong Chen. The research of vehicle power transmission system simulation. Xi'an: Shanxi University of Science \& Technology, 2013.

[19] Liangliang Yue. Matching research of vehicle engine and transmission system based on MATLAB and VC++ mixed programming. Wuhan: Wuhan University of Technology, 2010.

[20] Wenchun Zhang. Theory of vehicle. Beijing: China Machine Press, 2010.

[21] Guohua Tian. Automobile dynamic property test. Beijing: China Communications Press, 2002.

[22] Zhongming Xu; Shengyun Xiao; Fujian He. Foundation of automobile application engineering. Chongqing: Chongqing University Press, 2005.

[23] Qin Su. Matching simulation calculation between engine and automobile dynamical and fuel economy characteristic. Hebei: Hebei University of Technology, 2000.

[24] Xiaohua Zeng; Weijun Gong. Simulation and development application of the electric vehicle based on ADVISOR 2002 Beijing: China Machine Press, 2014.

[25] Fuxing Zhang. Study on driving cycles of city vehicle. Wuhan: Wuhan University of Technology, 2005.

[26] National Development and Reform Commission. The general technical condition of the flameproof diesel vehicle with the rubber wheels for the mine. MTT 989-2006. http://www.doc88.com/p-482729757884.html

[27] Yonggang Wei; Minggang Zhao; Guoying Meng. Discussion on tail gas control technology of mine flame proof diesel engine in underground coal mine. // Coal Science and Technology. 36, 12(2008), pp. 63-65. https://doi.org/10.13199/j.cst.2008.12.67.weiyg.033

\section{Authors' addresses}

\section{Jiusheng Bao}

School of Mechanical and Electrical Engineering, China University of Mining and Technology 221116, Xuzhou, China

Jiangsu Collaborative Innovation Center of Intelligent Mining Equipment, China University of Mining and Technology 221008, Xuzhou, China

E-mail: cumtbjs@126.com

\section{Shuai Yang}

School of Mechanical and Electrical Engineering, China University of Mining and Technology

221116, Xuzhou, China

E-mail: 842453659@qq.com

Shirong Ge, Corresponding author

School of Mechanical and Electrical Engineering, China University of Mining and Technology 221116, Xuzhou, China

Jiangsu Collaborative Innovation Center of Intelligent Mining Equipment, China University of Mining and Technology 221008, Xuzhou, China

E-mail: gesr@cumt.edu.cn

\section{Peixin Han}

School of Mechanical and Electrical Engineering, China University of Mining and Technology

221116, Xuzhou, China

E-mail:1527150728@qq.com

\section{Yan Yin}

School of Mechanical and Electrical Engineering, China University of Mining and Technology 221116, Xuzhou, China

E-mail: cumtyinyan@163.com 